\title{
Characterization and Complementation of a Mutant of Rhodobacter sphaeroides with a Chromosomal Deletion in the Light-harvesting (LH2) Genes
}

\author{
By J. GRANT BURGESS, $\uparrow$ MARK K. ASHBY $\ddagger$ AND C. NEIL HUNTER* $\dagger$ \\ Department of Pure and Applied Biology, Imperial College, Prince Consort Road, \\ London SW7 2BB, UK
}

(Received 13 December 1988; revised 29 March 1989; accepted 30 March 1989)

\begin{abstract}
An $\mathrm{LH}_{2}-$ strain of Rhodobacter sphaeroides, $\mathrm{DBC} 1$, has been constructed by deleting the puc operon, which encodes the $\mathrm{LH} 2 \alpha$ and $\beta$ polypeptides, from the chromosome and replacing it with a kanamycin resistance gene. Southern blot analysis indicates that the $950 \mathrm{bp} \mathrm{BamHI}$ restriction fragment which contains the puc operon has been lost and has been replaced by the $1.25 \mathrm{~kb} \mathrm{Km}^{\mathrm{R}}$ cassette derived from Tn903. Strain DBC1 lacked the LH2 complex, as shown by loss of the characteristic absorbance bands at 800 and $850 \mathrm{~nm}$. The LH2 polypeptides were also found to be absent after SDS-PAGE. The wild-type phenotype was restored to DBC1 by the transfer of a $3.8 \mathrm{~kb} B s c \mathrm{I}$ fragment containing the puc operon in plasmid pMA81. Transconjugants possessed a wild-type absorbance spectrum and $\mathrm{LH} 2$ polypeptides.
\end{abstract}

\section{INTRODUCTION}

The photosynthetic bacterium Rhodobacter sphaeroides has a relatively simple photosystem, consisting of the reaction centre and $\mathrm{LHI}$ antenna complexes surrounded by a peripheral lightharvesting system, LH2 (Vos et al., 1986). These antenna polypeptides bind bacteriochlorophyll (bchl) and are interconnected to form highly efficient domains for light capture and energy transfer. Excitation energy is transferred to the 'special pair' bchls of the reaction centre, where the primary photochemical events occur. The genes encoding the reaction centre $L$ and $M$, and the $\mathrm{LH} 1 \alpha$ and $\mathrm{LH} 1 \beta$ polypeptides are encoded on the puf operon, and their nucleotide sequences have been determined (Williams et al., 1983, 1984; Kiley et al., 1987). The reaction centre $\mathrm{H}$ gene is encoded on a separate operon, puh (Donohue et al., 1986). The LH2 $\alpha$ and LH2 $\beta$ polypeptides are encoded on the puc operon and their DNA sequences are also known (Ashby $e t$ al., 1987; Kiley \& Kaplan, 1987). The amount of LH1 relative to the reaction centre complex remains relatively constant with changes in growth conditions, whereas the amount of LH2 complex increases when light intensity and oxygen levels change (Aagaard \& Sistrom, 1972; Niederman et al., 1976). This phenomenon also occurs in Rhodobacter capsulatus (Schumacher \& Drews, 1979). Zucconi \& Beatty (1988) have proposed a post-transcriptional mechanism for the regulation of steady-state levels of mature LH2 complexes in Rb. capsulatus. The regulation of the puc operon in $R b$. sphaeroides is less well understood and may be affected indirectly by a number of factors (see Kiley \& Kaplan, 1988). Clearly, strains with mutant light-harvesting systems, or strains with mutations in regulatory regions of the puc operon, will be useful in probing the function and regulation of these antenna complexes.

$\dagger$ Present address: Biochemistry Section, Division of Molecular Biology and Biotechnology, University of Sheffield, Western Bank, Sheffield S10 2TN, UK.

$\ddagger$ Present address: Department of Cellular and Molecular Biology, The University of Auckland, Private Bag, Auckland, New Zealand.

Abbreviations: bchl, bacteriochlorophyll; RC, reaction centre; LH1, B875 antenna complex; LH2, B800-850 antenna complex. 
The use of light-harvesting mutants for the study of excitation energy transfer has so far proved valuable for the detailed analysis of the energetic interactions between the three photosynthetic components in vivo (Hunter \& van Grondelle, 1988; van Dorssen et al., 1988; Vos et al., 1988). The LH2 complex may be assembled from units consisting of three $\alpha$ and three $\beta$ polypeptides, together with six $850 \mathrm{~nm}$ bchls, three $800 \mathrm{~nm}$ bchls and six carotenoid molecules (Hunter et al., 1989). LH2 is the major light-harvesting pigment-protein complex in the membrane and has been well characterized biophysically (Kramer et al., 1984; van Dorssen et al., 1988). It would, therefore, be an ideal model system for more detailed mutational analysis of the structure and function of the LH2 antenna, particularly with regard to the importance of residues conserved in the antenna polypeptides of a number of photosynthetic bacteria (Brunisholz \& Zuber, 1988). It is with this purpose in mind that an LH2 deletion/insertion mutant of $R b$. sphaeroides has been constructed, since such a mutant provides a null genetic background against which altered complexes may be analysed in vivo. Youvan et al. (1985) have also constructed a puc deletion strain in $R b$. capsulatus which is spectrally similar to the previously described $\mathrm{LH}^{-}$Rb. sphaeroides mutant M21 (Ashby et al., 1987). One valuable aspect of such an $\mathrm{LH}^{-}$strain is that it permits a systematic investigation into the properties of the LH1/RC core complex in the photosynthetic membrane (van Dorssen et al., 1988; Hunter \& van Grondelle, 1988). The reversion rate of M21 (about $10^{-6}$ ), and the lack of information concerning the precise nature of the mutation, provide reasons for constructing a stable, genetically well-defined $\mathrm{LH} 2^{-}$mutant in $R b$. sphaeroides.

In this study we report the sequence of a $1078 \mathrm{bp} X h o \mathrm{I}-\mathrm{PvuII}$ restriction fragment which appears to contain only two genes, $p u c A$ and $B$. The deletion of the LH2 genes and subsequent insertion of the $\mathrm{Km}^{\mathrm{R}}$ cassette to form the mutant $\mathrm{DBCl}$, together with its genetic and biochemical characterization, are presented. We have restored this mutant to its parent phenotype by transfer of the cloned genes, demonstrating its suitability as a background for mutational analysis of regulatory or structural genes for $\mathrm{LH} 2$ synthesis. We envisage that such a mutant will be essential for testing functional models that describe the assembly, regulation and energy transfer properties of the LH2 antenna.

Table 1. Bacterial strains and plasmids

\begin{tabular}{|c|c|}
\hline Strain or plasmid & Relevant characteristics \\
\hline $\begin{array}{l}\text { E. coli } \\
\text { DH5 }\end{array}$ & $\begin{array}{l}\text { A derivative of DHl (which is } \mathrm{F}^{-} \text {recA endA gyrA } \\
\text { thi- } I \text { hsdR supE) }\end{array}$ \\
\hline Smlo & $\begin{array}{l}\text { rec } A \text { thi thr leu; } \mathrm{RP} 4-2-\mathrm{Tc}:: \mathrm{Mu} \text { integrated into the } \\
\text { chromosome; Tra }{ }^{+} \mathrm{Km}^{\mathrm{R}}\end{array}$ \\
\hline S17-1 & 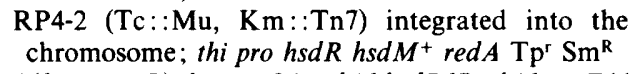 \\
\hline JM105 & $\begin{array}{l}\Delta(\text { lac-pro } A B) \text { thi gyrA } 96 \text { end } A 1 \text { hsdR } 17 \text { relA I supE } 44 \\
\left(\mathrm{r}_{\mathrm{K}^{-}}, \mathrm{m}_{\mathrm{K}^{-}}\right)\left[\mathrm{F}^{\prime} \text { traD36 proAB lacI } \mathrm{Z} \Delta M 15\right]\end{array}$ \\
\hline $\begin{array}{l}\text { Rb. sphaeroides } \\
\text { NCIB } 8253 \\
\text { DBC1 } \\
\text { DBC } 1.81\end{array}$ & $\begin{array}{l}\text { Wild-type } \\
\mathrm{Km}^{\mathrm{R}}, \mathrm{LH}^{-} \\
\mathrm{Sm}^{\mathrm{R}} \mathrm{Km}^{\mathrm{R}}, \mathrm{LH}^{+}\end{array}$ \\
\hline $\begin{array}{l}\text { Plasmids } \\
\text { pSUP202 } \\
\text { pMA81 }\end{array}$ & $\begin{array}{l}\mathrm{Ap}^{\mathrm{R}} \mathrm{Tc}^{\mathrm{R}} \mathrm{Cm}^{\mathrm{R}} ; \mathrm{Mob}^{+} \mathrm{Tra}^{-} ; \text {ColE1 replicon } \\
\mathrm{Sm}^{\mathrm{R}} ; \mathrm{Mob}^{+} ; 3.8 \mathrm{~kb} \text { Bsc I chromosomal fragment } \\
\text { from } R b . \text { sphaeroides containing pucAB cloned into } \\
\text { pNH2 }\end{array}$ \\
\hline pMAT81 & $\begin{array}{l}\mathrm{Ap}^{\mathrm{R}} \mathrm{Tc}^{\mathrm{S}} ; 3.8 \mathrm{~kb} \text { Bsc I chromosomal fragment from } \\
R b . \text { sphaeroides containing pucAB cloned into } \\
\text { pAT153 }\end{array}$ \\
\hline pMSK 11 & $\mathrm{Ap}^{\mathrm{R}} \mathrm{Cm}^{\mathrm{R}} \mathrm{Km}^{\mathrm{R}} \mathrm{Tc} \mathrm{s} ; \mathrm{Mob}^{+}$ \\
\hline
\end{tabular}

Source*

V.S.

R.S.

R.S.

S. A.C.

R.A.N.

This work

This work

R.S. Simon et al. (1983)

M.K.A. Ashby et al. (1987)

This work

This work
Hanahan (1985)

Simon et al. (1983)

Simon et al. (1983)

Messing et al. (1981)

* V.S., Dr V. Simanis, ICRF, London; R.S., Dr R. Simon, University of Bielefeld, FRG; R. A. N., Professor R. A. Niederman, Rutgers University, NJ, USA; S. A.C., S. Coomber, Imperial College, London; M. K. A., M. Ashby, University of Auckland, New Zealand. 
10 30

CTCGAGCGGTTCGAGTCGGTGCTCGCGGGCCCTGTCGATAGTAGCGGGGCTGTATTGAGG

$70 \quad 90 \quad 110$

CAGAGGCCGCCAAGCCATCCTGAAATCTCGAAAAATCCCCGCAAGATGGGGTCCGGAAGG

$130 \quad 150 \quad 170$

GCCGGGCGCAAGGCCTCGGACACCCTCGTTTTTGCAGCAGCGAGAGGCTGCGGGACGGCC

$190210 \quad 230$

CTGTGGGGCCGGGACACGCAGCGTCAATTTCCCGCGCGCCTGCGGCAAAATTGTCCCTTT

$250 \quad 270 \quad 290$

TCAAGCCGTTACGCAGGATTCCCGGCCGATCTGGCGGCCAATAAGTCGCACCCAAAACGG

$310 \quad 330 \quad 350$

CCTTGTCAGCCAACAGTGACATTGAATCTGTCAGCGCAATGTGACACCCATAATGCGAGC

$370 \quad 390 \quad 410$

CGGGGCGGATCAGAAATCGCCGACAAGGTGATCCAGGTCTCTCCGGTCTCGTCGAAGCCC

$430 \quad 450 \quad 470$

GCGTGCAGGCCCTACACGCAAACCGTCGATTTACCAGTTGGGAGACGACACAATGACTGA

pucB MetThras

$490 \quad 510 \quad 530$

CGATCTGAACAAAGTCTGGCCGAGCGGCCTGACCGTTGCCGAAGCCGAAGAAGTTCATAA pAspLeuAsnLysValTrpProSerGlyLeuThrVaIAlaGluAlaGluGluValHisLy

$550 \quad 570 \quad 590$

GCAACTCATCCTCGGCACCCGCGTCTTCGGTGGCATGGCGCTCATCGCGCACTTCCTCGC sGlnLeuIleLeuGlyThrArgValPheGlyGlyMe tAlaLeuIleAlaHisPheLeuAl

$\begin{array}{ccc}610 & 630 & 650 \\ \text { CGCCGCTGCGACCCCGTGGCTCGGCTGATAGGAGAAGACTGACATGACCAACGGCAAAAT } & \text { pucA } A \text { MetThrAsnGlyLysIl } \\ \text { aAlaAlaAlaThrProTrpLeuGly } & \end{array}$

$670 \quad 690 \quad 710$

CTGGCTCGTGGTGAAACCGACCGTCGGCGTTCCGCTGTTCCTCAGCGCTGCCGTCATCGC eTrpLeuValValLysProThrValGlyValProLeuPheLeuSerAlaAlaValrleAl

$730 \quad 750 \quad 770$

CTCCGTCGTTATCCACGCTGCTGTGCTGACGACCACCACCTGGCTGCCCGCCTACTACCA aSerValValIleHisAlaAlaValLeuThrThrThrThrTrpLeuProAlaTyrTyrGl

$\begin{array}{lll}790 & 810 & 830\end{array}$

AGGCTCGGCTGCGGTCGCGGCCGAGTAATGCTGCGCAAGGCGCGGGCCTGCGGGCCCACG nGlySerAlaAlaValalaAlaGlu

$850 \quad 870 \quad 890$

CCAGCCAGTCCGTGAGTTCCGAGCAGGCCGGGATCCTTGGGTTCCGGCTGCTCGTCACAC

$910 \quad 930 \quad 950$

CAGCGACGTGTTCCTGTCGCCTTGCCCGTTCGGGCTGTGTGCCTGAAGCCCGAGATCCTT

$970 \quad 990 \quad 1010$

TCCAGTCGCGCAGTCTGCGCCTACCCCGGGATTCTTCACGCATGAGCCGAATTGCCGAAC

$1030 \quad 1050 \quad 1070$

ATCTGGTCCGCATCGGACCGCGGTTTCTGCCATTTCCGACGCGGCCTCGGACCAGCTG

Fig. 1. Sequence of a 1078 bp $X h o I-P v u I I$ fragment containing the $p u c A$ and $B$ genes. Open reading frames corresponding to $p u c A$ and $p u c B$ are indicated by the gene products. 


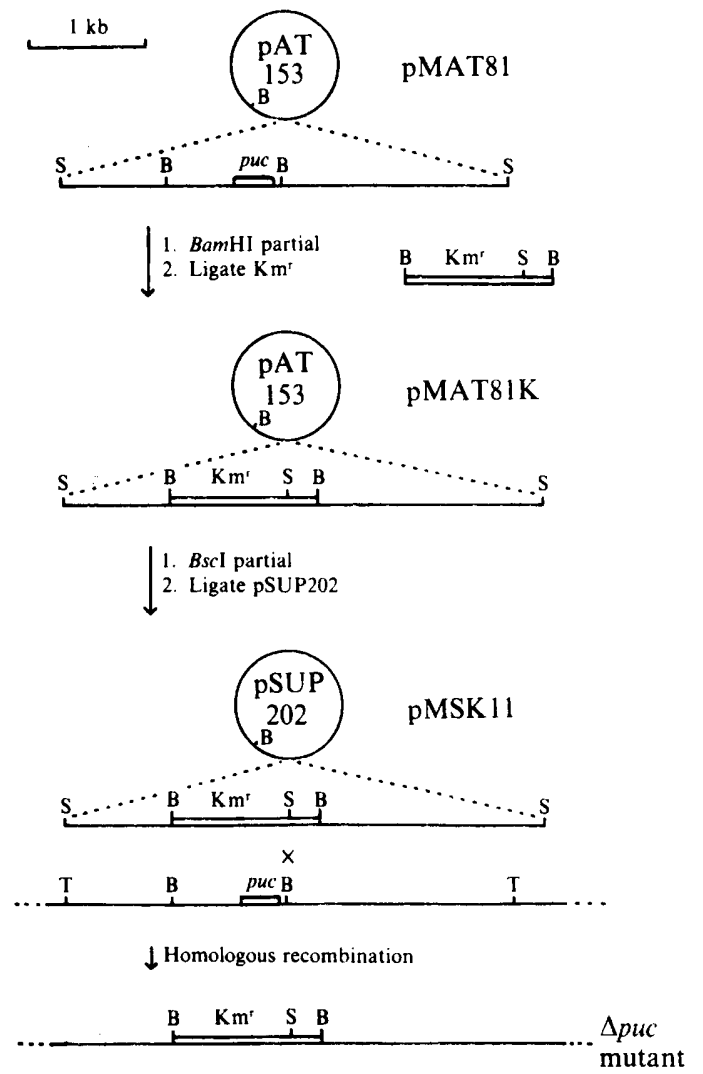

Fig. 2. Construction of $\mathrm{DBCl}$, showing the restriction map of the cloned $3.8 \mathrm{~kb} \mathrm{BscI}$ fragment, the $\mathrm{Km}^{\mathrm{R}}$ cassette and the cassette integrated into the $R b$. sphaeroides chromosome. Restriction enzymes: $\mathrm{B}$, BamHI; S, BscI; T, TaqI.

\section{METHODS}

Media and antibiotics. Escherichia coli strains were grown in LB medium. Rb. sphaeroides was grown in M22+ medium (Hunter \& Turner, 1988) supplemented with $0 \cdot 1 \%$ Casamino acids. Antibiotics were used at the following concentrations $\left(\mu \mathrm{g} \mathrm{mg}^{-1}\right): E$. coli, ampicillin 50 , chloramphenicol 25 , kanamycin 30 , streptomycin $50 ; R b$. sphaeroides, kanamycin 20, streptomycin 50.

Bacterial strains and plasmids. These are listed in Table 1.

Preparation and analysis of DNA. Plasmid and genomic DNA were prepared as described previously (Hunter \& Turner, 1988). Restriction analysis, agarose gel electrophoresis and Southern hybridizations were performed as described in Maniatis et al. (1982). Radioactive DNA probes were made by the mixed oligonucleotide fragment labelling method of Feinberg \& Vogelstein (1983). DNA sequencing was performed on M13mp18/19 clones using the dideoxy procedure of Sanger et al. (1977). Colony lysis and filter screening was by the method of Woods (1984).

Preparation of intracytoplasmic membranes. $R b$. sphaeroides cells were harvested by centrifugation after photosynthetic growth and membranes were prepared as described by Hunter \& Turner (1988).

Spectroscopy. Room-temperature absorbance spectra of whole cells and purified membranes were obtained using a Perkin Elmer 554 spectrophotometer.

SDS-PAGE. Purified membranes were analysed on polyacrylamide gradient gels using the buffer system described by Tadros et al. (1982) and an acrylamide gradient of $12-20 \%(\mathrm{w} / \mathrm{v})$.

Plasmid transfer. The plasmids pMA81 and pMSK11 were transferred from E. coli strains Sm10 and S17-1, respectively, by a conjugative transfer procedure described by Hunter \& Turner (1988).

\section{RESULTS AND DISCUSSION}

The sequence of a 1078 bp $X h o I-P v u I I$ restriction fragment containing the puc operon is shown in Fig. 1. The pucB and $\boldsymbol{A}$ genes are encoded by open reading frames of $150 \mathrm{bp}$ and $164 \mathrm{bp}$, respectively, and are separated by a $15 \mathrm{bp}$ spacer region; no other reading frames are 

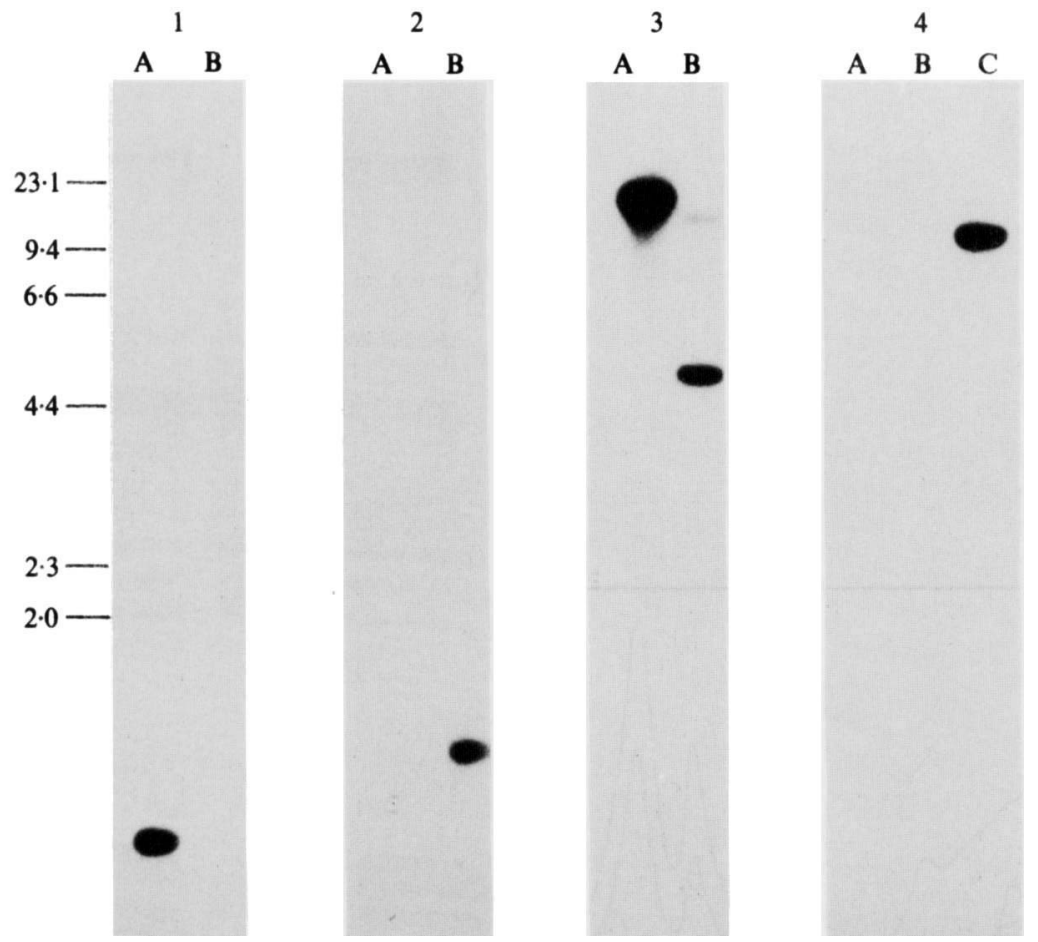

Fig. 3. Southern hybridization of: tracks A, NCIB 8253 genomic DNA; tracks B, DBCl genomic DNA; track C, pMSK 11. Blots 1 and 2 were digested with Bam HI, blots 3 and 4 with BscI. Probes used : 1, 950 bp Bam HI puc fragment; 2, 1.25 kb Bam HI Km ${ }^{\mathrm{R}}$ cassette; 3, 3.8 kb BscI puc fragment; 4, pSUP202.

present. A single transcript of $0.55 \mathrm{~kb}$ can be detected by Northern blot analysis using either the $950 \mathrm{bp} \mathrm{BamHI}$ or the $1078 \mathrm{bp} X h o \mathrm{I}-P v u \mathrm{II}$ fragment as a probe. The sequence presented represents all but $60 \mathrm{bp}$ of the $950 \mathrm{bp} \mathrm{Bam} \mathrm{HI} \mathrm{fragment} \mathrm{deleted} \mathrm{from} \mathrm{the} \mathrm{chromosome} \mathrm{to} \mathrm{produce}$ $\mathrm{DBCl}$ (see Fig. 2), suggesting that only the puc genes are encoded in this region.

Deletion of the puc operon from plasmid pMA81 was accomplished by removing a $950 \mathrm{bp}$ $B a m \mathrm{HI}$ fragment from the cloned $3.8 \mathrm{bp} \mathrm{BscI}$ fragment (Ashby et al., 1987). This was replaced with a $2.25 \mathrm{~kb}$ Bam HI-ended kanamycin resistance gene from transposon Tn903. The $4.0 \mathrm{~kb}$ $B c s$ I fragment containing the $\mathrm{Km}^{\mathrm{R}}$ cartridge was then cloned into the mobilizable suicide vector pSUP202 (Simon et al., 1983). This construct, pMSK11, was transferred into wild-type $R b$. sphaeroides NCIB 8253 by conjugative transfer from $E$. coli S17-1 (Simon et al., 1983). Photosynthetic, kanamycin-resistant $R b$. sphaeroides colonies were obtained, about half of which were smaller than the others. This was to be expected, since LH2-deficient strains would have a decreased light-harvesting capacity with only 330 bchls per photosynthetic domain, rather than the approximately 3000 bchls in wild-type cells (Vos et al., 1988).

Southern blot analysis of $R b$. sphaeroides strain DBCl (Fig. 3) confirmed the presence of the $\mathrm{Km}^{\mathrm{R}}$ gene in the chromosome and indicated deletion of the puc genes by a double recombination event (Niaudet et al., 1982); a single event would have led to the presence of both pSUP202 and puc DNA in the chromosome. In Fig. 3, blot 1 shows the absence of puc genes in DBC1 compared with the wild-type while blot 2 confirms the concomitant insertion of the $\mathrm{Km}^{\mathrm{R}}$ gene, which is not present in the wild-type. The $\mathrm{Km}^{\mathrm{R}}$ gene from $\mathrm{Tn} 903$ was used in preference to that from $\operatorname{Tn} 5$ since this latter transposon may also confer resistance to streptomycin. The puc operon is encoded on a $15 \mathrm{~kb} \mathrm{BscI}$ fragment as shown in Fig. 3, blot 3, track A. This region hybridizes with the $3.8 \mathrm{~kb} \mathrm{BscI}$ fragment from pMAT81. Note that the two BscI sites in pMAT81 (Fig. 2) 


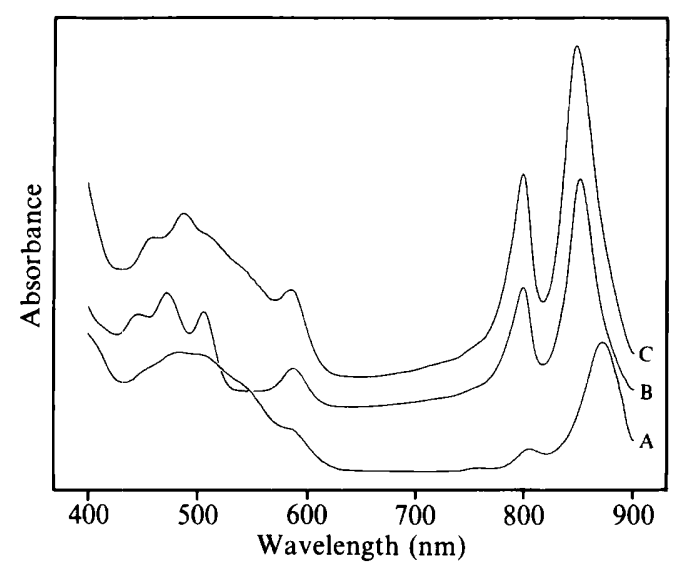

Fig. 4

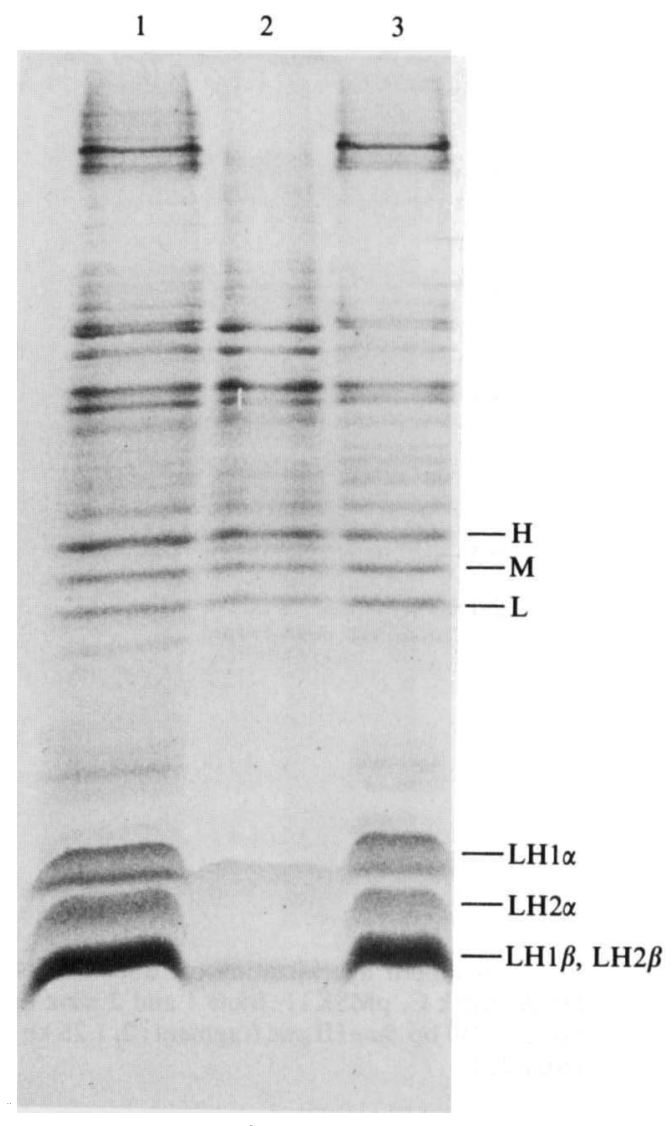

Fig. 5

Fig. 4. Room-temperature absorbance spectra of membrane preparations from: A, DBC1; B, DBC1.81; and C, wild-type NCIB 8253.

Fig. 5. SDS-PAGE of solubilized membranes. 1, Wild-type NCIB 8253; 2, DBC1; 3, DBC1.81.

have both arisen fortuitously as a result of the original cloning strategy in which partial Taq I genomic digests were cloned into the $B s c \mathrm{I}$ site of $\mathrm{pNH} 2$ (Hunter \& Turner, 1988). This $3.8 \mathrm{~kb}$ $B s c I$ fragment hybridizes to $10.5 \mathrm{~kb}$ and $4.5 \mathrm{~kb} \mathrm{BscI}$ fragments from $\mathrm{DBCl}$ (blot 3, track $\mathrm{B}$ ), indicating that a $15 \mathrm{~kb} \mathrm{BscI}$ fragment has been interrupted by the $B s c \mathrm{I}$ site in the $\mathrm{Km}^{\mathrm{R}}$ gene of Tn903. Fig. 3, blot 4 shows no hybridization between DBC1 genomic DNA and the plasmid pSUP202, indicating that this plasmid did not integrate into the chromosome, and that the deletion of the puc operon has occurred by a double recombination event which has replaced the $950 \mathrm{bp} \mathrm{Bam} \mathrm{HI}$ fragment with the $1.25 \mathrm{~kb}$ Bam HI fragment containing the $\mathrm{Km}^{\mathrm{R}}$ gene of $\mathrm{Tn} 903$.

The absorbance spectra of wild-type NCIB 8253, DBC1 and the complemented strain DBC1.81 are shown in Fig. 4. The wild-type shows the peaks at $800 \mathrm{~nm}$ and $850 \mathrm{~nm}$ characteristic of LH2 antenna complexes, as well as a shoulder at $875 \mathrm{~nm}$ due to the LH1 antenna. DBCl lacks these $800 \mathrm{~nm}$ and $850 \mathrm{~nm}$ absorbance peaks and instead exhibits an absorbance maximum at $875 \mathrm{~nm}$, which arises from the LH1 antenna, together with a small peak near $800 \mathrm{~nm}$ due to reaction centres. Thus, the absorbance spectra indicate that the LH2 complex is not present in the membrane of DBC1 but the LH1/RC core (Vos et al., 1988) remains.

SDS-PAGE analysis of photosynthetic membranes is shown in Fig. 5. Track 1 shows the three low-molecular-mass bands that are observed in the wild-type; they arise from LH1 $\alpha$, LH $2 \alpha$ and superimposed LH1 $\beta$ and LH2 $\beta$, in decreasing molecular size (Broglie et al., 1979). The upper 
band $\mathrm{LH} \alpha$ is 6809 daltons, the middle band $\mathrm{LH} 2 \alpha$ is 5599 daltons and the lower band arises from LH1 $\beta$ (5441 daltons) and LH2 $\beta$ (Theiler et al., 1984, 1985) (5448 daltons). The LH $2 \alpha$ and $\beta$ polypeptides are absent from $\mathrm{DBCl}$ membranes because the puc gene has been lost (track 2 ). The remaining bands are $\mathrm{LH} 1 \alpha$ and $\beta$.

The $p u c A$ and $B$ genes were transferred to $\mathrm{DBCl}$ in an attempt to complement the mutation. The plasmid pMA81 (Ashby et al., 1987), which contains the puc operon as a $3.8 \mathrm{~kb} B s c \mathrm{I}$ fragment, was transferred to $\mathrm{DBCl}$ by conjugative transfer from $E$. coli Sm10. Streptomycinresistant, photosynthetic colonies were obtained. Colonies were cultured photosynthetically for spectral analysis. One transconjugant strain was found, $\mathrm{DBC} 1.81$, which exhibited the characteristic LH2 absorbance peaks (Fig. 4). SDS-PAGE analysis of membranes from DBC1.81 showed that the B800-850 polypeptides had been restored (Fig. 5, track 3).

In this work we have reported the construction of an $R b$. sphaeroides chromosomal deletion mutant for the puc genes resulting in a mutant deficient in the secondary light-harvesting complex LH2. This complex has been successfully restored to the mutant by conjugative gene transfer, indicating that $\mathrm{DBC} 1$ is a suitable recipient for mutagenized $\mathrm{LH} 2$ genes.

The authors acknowledge the financial support of the Agricultural and Food Research Council of Great Britain and would like to thank John Olsen for expert technical assistance.

\section{REFERENCES}

AagaARD, J. \& Sistrom, W. R. (1972). Control of synthesis of reaction center bacteriochlorophyll in photosynthetic bacteria. Photochemistry and Photobiology 15, 209-225.

Ashby, M. K., COOMber, S. A. \& Hunter, C. N. (1987). Cloning, nucleotide sequence and transfer of genes for the B800-850 light harvesting complex of Rhodobacter sphaeroides. FEBS Letters 213, 245-248.

Broglie, R. M., Hunter, C. N., Delepelaire, P., Niederman, R. A., Chua, N. H. \& Clayton, R. K. (1979). Isolation and characterisation of the pigment protein complexes of Rhodopseudomonas sphaeroides by lithium dodecyl sulphate polyacrylamide gel electrophoresis. Proceedings of the National Academy of Sciences of the United States of America 77, 87-91.

Brunisholz, R. A. \& ZUBER, H. (1988). Primary structure analysis of bacterial antenna polypeptides. In Photosynthetic Light Harvesting Systems: Organisation and Function, 1st edn, pp. 103-114. Edited by H. Scheer \& S. Schneider. Berlin \& New York: Walter de Gruyter.

Donohue, T J., Hoger, J. H. \& Kaplan, S. (1986). Cloning and expression of the Rhodobacter sphaeroides reaction centre $\mathrm{H}$ gene. Journal of Bacteriology 168, 953-961.

van Dorssen, R. J., Hunter, C. N., van Grondelle, R., KorenhoF, A. H. \& AMEsZ, J. (1988). Spectroscopic properties of antenna complexes of Rhodobacter sphaeroides in vivo. Biochimica et biophysica acta 932, 179-188.

Feinberg, A. P. \& Vogelstein, B. (1983). A technique for radiolabelling DNA restriction fragments to high specific activity. Analytical Biochemistry 132, 6-13.

HaNAHAN, D. (1985). Techniques for the transformation of E. coli. In DNA Cloning, vol. 1, 1st edn, pp. 109-135. Edited by D. M. Glover. Oxford: IRL Press.

HunTER, C. N. \& TURner, G. (1988). Transfer of genes coding for apoproteins of reaction centre and lightharvesting $\mathrm{LH} 1$ complexes to Rhodobacter sphaer- oides. Journal of General Microbiology 134, 14711480.

Hunter, C. N. \& van Grondelle, R. (1988). The use of mutants to investigate the organisation of the photosynthetic apparatus of Rhodobacter sphaeroides. In Structure and Function in Photosynthetic Light Harvesting Systems, pp. 247-260. Edited by H. Scheer \& S. Schneider. Berlin: Walter De Gruyter.

Hunter, C. N., van Grondelle, R. \& Olsen, J. D. (1989). Photosynthetic antenna proteins: $100 \mathrm{ps}$ before photochemistry starts. Trends in Biochemical Sciences 14, 72-76.

Kiley, P. J. \& KaPlaN, S. (1987). Cloning, DNA sequence, and expression of the Rhodobacter sphaeroides light-harvesting $\mathrm{B} 800-850 \alpha$ and $\mathrm{B} 800-850 \beta$ genes. Journal of Bacteriology 169, 3268-3275.

KILEY, P. J. \& KAPLAN, S. (1988). Molecular genetics of photosynthetic membrane biosynthesis in Rhodobacter sphaeroides. Microbiological Reviews 52, 5069.

Kiley, P. J., Donohue, T. J., Havelka, W. A. \& KaPlaN, S. (1987). DNA sequence and in vitro expression of the B875 light-harvesting polypeptides of Rhodobacter sphaeroides. Journal of Bacteriology 169, 742-750.

Kramer, H. J. M., van Grondelle, R., Hunter, C. N., Westerhuis, W. H. J. \& Amesz, J. (1984). Pigment organisation of the B800-850 antenna complex of Rhodopseudomonas sphaeroides. Biochimica et biophysica acta 765, 156-165.

Maniatis, T., Fritsch, E. F. \& SAmbroOK, J. (1982). Molecular Cloning. A Laboratory Manual. Cold Spring Harbor, NY: Cold Spring Harbor Laboratory.

Messing, J., Grea, R. \& Seeburg, P. H. (1981). A system for shotgun DNA sequencing. Nucleic Acids Research 9, 309-321.

Niaudet, B., Goze, A. \& Ehrlich, S. D. (1982). Insertional mutagenesis in Bacillus subtilis: mechanism and use in gene cloning. Gene 19, 277-284. 
Niederman, R. A., Mallon, D. E. \& Langan, J. J. (1976). Membranes of Rhodopseudomonas sphaeroides. IV. Assembly of chromatophores in low aeration cell suspensions. Biochimica et biophysica acta 440, 429-447.

SANGer, F., Nicklen, S. \& Coulsen, A. R. (1977). DNA sequencing with chain terminating inhibitors. Proceedings of the National Academy of Sciences of the United States of America 80, 6505-6509.

Schumacher, A. \& Drews, G. (1979). The effects of light intensity on membrane differentiation in Rhodopseudomonas capsulata. Biochimica et biophysica acta 547, 417-428.

Simon, R., Priefer, U. \& Puhler, A. (1983). A broad host range mobilization system for in vivo genetic engineering: transposon mutagenesis in Gramnegative bacteria. Bio/Technology 1, 784-791.

Tadros, M. H., Zuber, H. \& Drews, G. (1982). The polypeptide components from the light-harvesting pigment-protein complex II (B800-850) of Rhodopseudomonas capsulata. European Journal of Biochemistry 127, 315-318.

Theiler, R., SUter, F., Zuber, H. \& COGdell, R. J. (1984). A comparison of the primary structures of the two B800-850-apoproteins from wild-type Rhodopseudomonas sphaeroides strain 2.4 .1 and a carotenoid-less mutant strain R26.1. FEBS Letters 175, 231-237.

Theiler, R., Suter, F., Pennoyer, J. D., Zuber, H. \& Niederman, R. A. (1985). Complete amino acid sequence of the B875 light-harvesting protein of Rhodopseudomonas sphaeroides strain 2.4.1. FEBS Letters 184, 231-236.

Vos, M., van Grondelle, R., van de KoOIJ, F. W., van DE Poll, D., Amesz, J. \& DuYsens, L. N. M. (1986). Singlet-singlet annihilation at low tempera- tures in the antenna of purple bacteria. Biochimica et biophysica acta 850, 501-512.

Vos, M., van Dorssen, R. J., AMESz, J., VAN Grondelle, R. \& Hunter, C. N. (1988). The organisation of the photosynthetic apparatus of Rhodobacter sphaeroides: studies of antenna mutants using singlet-singlet quenching. Biochimica et biophysica acta 933, 132-140.

Williams, J. C., Steiner, L. A., Ogden, R. C., Simon, M. I. \& FeHER, G. (1983). Primary structure of the M subunit of the reaction centre from Rhodopseudomonas sphaeroides. Proceedings of the National Academy of Sciences of the United States of America 80, 6505-6509.

Williams, J. C., Steiner, L. A., Feher, G. \& Simon, M. I. (1984). Primary structure of the $L$ subunit of the reaction centre from Rhodopseudomonas sphaeroides. Proceedings of the National Academy of Sciences of the United States of America 81, 7303-7308.

Woods, D. (1984). Oligonucleotide screening of cDNA Libraries. Focus (Bethesda Research Laboratories) 6(3), 1-3.

Youvan, D. C., Ismail, S. \& Bylina, E. J. (1985). Chromosomal deletion and plasmid complementation of the photosynthetic reaction centre and light harvesting genes from Rhodopseudomonas sphaeroides. Gene 38, 19-30.

ZUBER, H. (1986). Structure of the light-harvesting antenna complexes of photosynthetic bacteria, cyanobacteria and red algae. Trends in Biochemical Sciences 11, 414-419.

ZuCConi, A. P. \& BeatTy, J. T. (1988). Posttranscriptional regulation by light of the steady-state levels of mature B800-850 light-harvesting complexes in Rhodobacter capsulatus. Journal of Bacteriology 170 , 877-882. 